\title{
ОБґРУНТУВАННЯ ЕФЕКТИВНОСТІ ІНФОРМАЦІЙНИХ ТА ТЕЛЕМЕДИЧНИХ ТЕХНОЛОГІЙ ДЛЯ ПОКРАЩЕННЯ ЯКОСТІ МЕДИЧНОЇ ДОПОМОГИ СІЛЬСЬКОМУ НАСЕЛЕННЮ
}

\author{
В. П. Марценюк, П. Р. Сельський \\ двн3 "Тернопільський державний медичний університет імені І. Я. Горбачевського \\ МО3 україни"
}

В статті розкрито досвід впровадження інформаційних та телемедичних технологій у навчально-практичних центрах первинної медико-санітарної допомоги, відкритих Тернопільським державним медичним університетом імені І. Я. Горбачевського. Показано ефективність інформатизації на первинному рівні для покращення якості медичного обслуговування сільського населення та підготовки висококваліфікованих спеціалістів.

Ключові слова: інформаційні технології, телемедицина, первинна медико-санітарна допомога.

\section{ОБОСНОВАНИЕ ЭФФЕКТИВНОСТИ ИНФОРМАЦИОННЫХ И ТЕЛЕМЕДИЦИНСКИХ ТЕХНОЛОГИЙ ДЛЯ УЛУЧШЕНИЯ КАЧЕСТВА МЕДИЦИНСКОЙ ПОМОЩИ СЕЛЬСКОМУ НАСЕЛЕНИЮ}

ГВуз "Тернопольский государственный
имени И. Я. Горбачевского мОЗ

\section{В. П. Марценюк, П. Р. Сельский}

медицинский университет

Украины", Тернополь

В статье раскрыт опыт внедрения информационных и телемедицинских технологий в учебно-практических центрах первичной медико-санитарной помощи, открытых Тернопольским государственным медицинским университетом имени И. Я. Горбачевского. Показана эффективность информатизации на первичном уровне для улучшения качества медицинского обслуживания сельского населения и подготовки высококвалифицированных специалистов.

Ключевые слова: информационные технологии, телемедицина, первичная медико-санитарная помощь.

\section{THE SUBSTANTIATION OF EFFICIENCY OF INFORMATION AND TELEMEDICINE TECHNOLOGIES ON PURPOSE FOR IMPROVING THE MEDICAL CARE QUALITY FOR RURAL POPULATION}

\author{
V. P. Martsenyuk, P. R. Selskyi \\ SHEI "Ternopii State Medical University by I. Ya. Horbachevsky" of MPH of Ukraine
}

\begin{abstract}
The article reveals the implementation experience of information and telemedicine health care service technologies in practical training centres of primary medical care, which have been opened by I. Ya. Horbachevsky Ternopil State Medical University. The efficiency of informational support at primary level, aimed to quality improvement the medical treatment of rural population and highly qualified specialist training have been shown.
\end{abstract}

Key words: information technologies, telemedicine health care service, primary medical care.

Вступ. Численні дослідження спрямовані на вирішення технологічних проблем впровадження інформаційних технологій, важливе місце в яких займає телемедицина i, зокрема, телемедичне консультування $[1,2,3,4]$. Система віддалених медичних консультацій використовується в тих областях медицини, де необхідно декілька компетентних думок у встанов(c) В. П. Марценюк, П. Р. Сельський ленні діагнозу [5]. Тут накопичено і певний досвід щодо використання телемедичних технологій $[6,7,8,9] .3$ метою забезпечення належної якості допомоги на первинному рівні існує потреба в накопиченні й аналізі даних [1]. Проте не до кінця вирішеною залишається проблема ефективного використання новітніх інформаційних технологій у сільській медицині, зокрема 
телемедичного консультування, та відповідної підготовки лікарів на додипломному і післядипломному етапі.

Метою роботи с обгрунтування ефективності використання інформаційних технологій для підвищення якості надання медичної допомоги на первинному рівні та підготовки висококваліфікованих спеціалістів.

Матеріали і методи. За 2009-2011 роки Тернопільським державним медичним університетом імені I. Я. Горбачевского за сприяння місцевої влади для впровадження новітніх навчальних методик у навчальний процес студентів випускного курсу і лікарівінтернів та покращення лікувально-профілактичної роботи на первинному рівні створені 5 начально-практичних центрів первинної медико-санітарної допомоги (НПЦПМСД). Всі заклади забезпечені інтернетом, аудіо-відео зв'язком. Кожний пункт обладнано базовими робочими станціями із мультимедійним персональним комп'ютером, принтером, а також комплектом спеціалізованих пристроїв: електрокардіографом Юкард-100 та мікроскопом із відеонасадкою. Для роботи із вищевказаним обладнанням наявне також стандартне, додаткове та спеціальне програмне забезпечення (драйвери принтерів та спеціалізованих пристроїв, програма для аналізу електрокардіограм "иКЕТ", морфометричні програми). Здійснюється передача алфавітно-цифрової, кольорової та динамічної візуально-графічної інформації. Програма «Реєстратура» передбачає введення анкетних даних всіх жителів села, де відмічаються діагностичні і лікувальні процедури, надані пацієнтам.

Результати й обговорення. НПЦМСД діють при амбулаторії загальної практики-сімейної медицини, 2ох ФАПах та 2-ох медичних пунктах в таких населених пунктах Тернопільської області: Зарубинці (Збаразький район), Гнилиці (Підволочиський район), Го вилів (Теребовлянський район), Увисла (Гусятинський район), Кокошинці (Гусятинський район). Метою НПЦПМСД є надання медичної допомоги населенню села, проходження практики студентами старших курсів і лікарями-інтернами медичного та стоматологічного факультетів, а також профорієнтація випускників для роботи в сільській місцевості. Такі центри створювались як зразок фельдшерсько-акушерських пунктів та лікарських амбулаторій (амбулаторій загальної практики - сімейної медицини) в розрізі програми реформування медичної галузі Тернопільської області та відповідно до ст. 30 та ст. 63 Закону України «Про вищу освіту». У структурі кожного НПЦПМСД передбачено кабінет лікаря загальної практики, стоматологічний кабінет, допоміжні кабінети, аптечний пункт та житловий блок зі всіма побутовими зручностями. Для забезпечення навчального процесу та надання первинної медичної допомоги у НПЦПМСД $є$ необхідна медична апаратура та інструментарій відповідно до затверджених MO3 України нормативів, зокрема Наказу МО3 № 132 від 23.02.12 p. "Про затвердження Примірного табеля оснащення лікувально-профілактичних підрозділів закладів охорони здоров'я, які надають первинну медичну (медико -санітарну допомогу)". Для студентів та лікарів-інтернів створені сучасні побутові умови.

Один раз на тиждень, а при потребі і частіше, в НПЦПМСД виїжджають лікарі-спеціалісти клінічних кафедр ТДМУ, які проводять спеціалізовані консультативні прийоми сільського населення. Викладачі клінічних кафедр, а також лікарі-інтерни при необхідності направляють пацієнтів у лікувально-профілактичні заклади другого рівня та в Тернопільську університетську лікарню. Стоматологічний кабінет для забезпечення навчального процесу оснащений сучасною стоматологічною установкою. НПЦПМСД здійснюють проведення навчальних профілактичних заходів для запобігання та зменшення захворюваності, своєчасного виявлення хворих, диспансеризації та надання первинної медичної допомоги населенню. Студенти та інтерни мають змогу ознайомитись 3 реаліями сільської медицини, набути навичок надання медичної допомоги цій категорії населення, що допоможе залучити майбутніх спеціалістів до роботи в сільській місцевості.

Інформатизація та автоматизація роботи НПЦПМСД здійснюється шляхом використання сучасних інформаційних технологій, баз даних, створення інформаційної системи та автоматизації робочого місця працівника. Інформаційна система центрів об'єднана 3 інформаційною системою університетської лікарні та кафедрами клініко-лабораторної діагностики і патологічної анатомії з секційним курсом та судової медицини університету в загальну інформаційну систему. Кожна з них має свою ієрархію збереження інформації та бази даних. При побудові інформаційної системи використано принцип програмної сумісності та можливість працювати з вільним програмним забезпеченням. Вона має блокову структуру за рівнем медичних закладів. Така побудова дає можливість розділення і нарощування з паралельною роботою в межах кожного блоку. Інформаційна система забезпечує оперативну передачу інформації, проведення конференцій, нарад, здійснення телемедичного консультування. 
У НПЦПМСД бази даних розділені на бази даних пацієнтів та бази даних послуг. Збереження та облік інформації здійснюється за допомогою програми "Реєстратура".

Ця програма дає можливість працювати з такими анкетними даними пацієнтів: прізвище, ім'я, по батькові, стать, дата народження, адреса, телефон, місце роботи, дата реєстрації та, за необхідності, інформація щодо пред'явленого документа. Під час амбулаторних прийомів лікар вносить всі дані суб' єктивного та об'єктивного обстежень, включно зі скаргами, результатами фізикального, лабораторного та інструментального обстежень. Це дає можливість динамічного спостереження за хворими, порівняння результатів обстеження, корекції лікування.

Вноситься також інформація про всі виконані діагностичні і лікувальні процедури. При цьому є можливість вносити найменування наданої послуги, дату i час, інформацію про виконавця, а також коментар щодо результатів, наприклад: "190/100 мм. рт. ст", "ЧСС - 65 уд./хв. Електрична вісь серця 17 градусів, горизонтальне положення, синусовий ритм". Перед- бачено також додавання інформації щодо лікування жителів села $з$ інших лікувальних закладів, включно iз результатами лабораторних та інструментальних обстежень. Електронна картотека зручна в користуванні для населення та забезпечує стандартизацію інформаційного обміну.

Паралельно із впровадженням інформаційних технологій здійснюється відповідна підготовка персоналу медичних пунктів, ФАПів та амбулаторії. Проводиться їх навчання в якості користувачів для роботи iз спеціальними програмами та базами даних. Для майбутньої роботи в сільських амбулаторіях здійснюється таке навчання і для студентів-випускників та лікарів-інтернів за спеціальністю "Загальна практика - сімейна медицина".

За допомогою засобів телемедичного консультування $\epsilon$ можливість консультацій хворих, які звертаються у начально-практичні центри первинної медико-санітарної допомоги, провідними спеціалістами Тернопільської університетської лікарні в режимі on-line (рис. 1). Здійснюється передача алфавітно-цифрової, кольорової та динамічної візуально-графічної інформації.

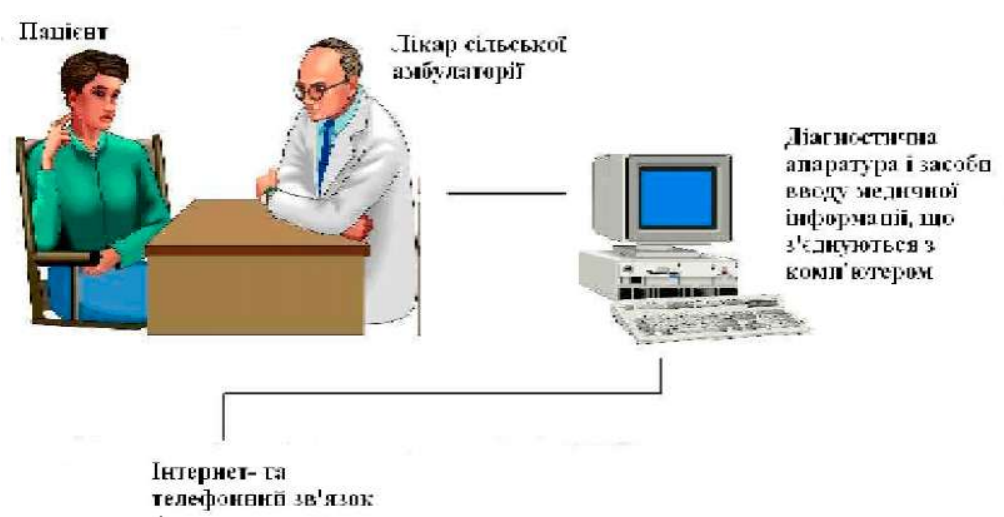

Puc. 1. Схема проведення сеансу

віддаленого консультування у НПЦПМСД.

3 метою ранньої діагностики серцевої патології та визначення доцільності госпіталізації електрокардіограми засобами GSM- та інтернет-зв'язку передаються у центр обробки та аналізу, який знаходиться на території університетської лікарні і обладнаний базовим мультимедійним персональним комп'ютером. Електронна база електрокардіограм допомогає у діагностиці серцевої патології при по-
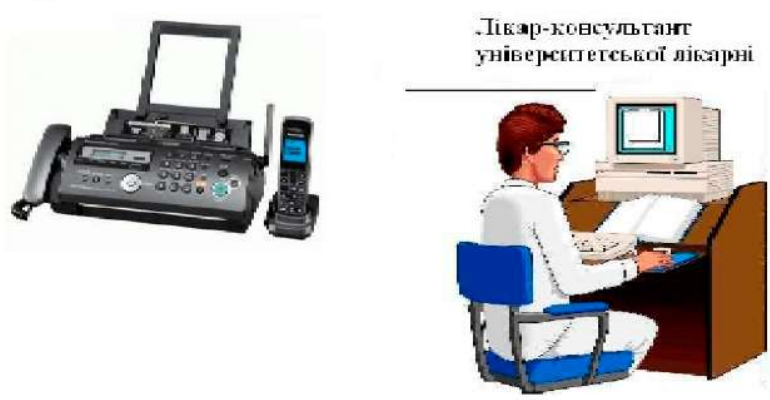

рівнянні результатів обстежень тих же пацієнтів у різні періоди. Перегляд та аналіз електрокардіограм здійснюється за допомогою програми "UNET" (рис. 2).

За допомогою даної програми є також можливість проведення аналізу результатів електрокардіографії в динаміці та амплітудно-часових характеристик у цифровому вигляді (рис. 3). 


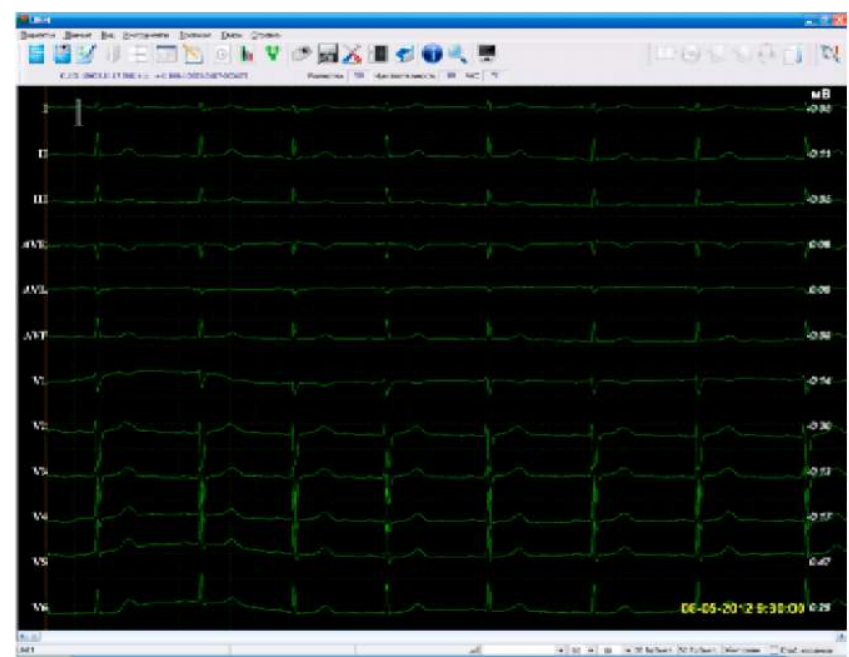

Puc. 2. Головне вікно програми "UNET" із можливістю аналізу результатів електрокардіографії у всіх відведеннях.

Цитологічна експрес-діагностика забезпечується за допомогою мікроскопів із цифровими відеокамерами та програмним аналізом зображення. За допомогою аудіо-відеозв'язку та передачі зображень гінекологічних мазків здійснюється консультування спеціалістами цитологами кафедр патологічної анатомії та клініко-лабораторної діагностики університету із можливістю морфометричного аналізу. У консультативному гістологічному висновку вказується прізвище, ім'я, по батькові пацієнта, вік, стать, № гістологічного (цитологічного) препарату, текст гістологічного висновку або консультативний гістологічний висновок, дата та інформація про лікаря-консультанта. Для проведення морфометричної обробки зображень розроблено програмний засіб в середовищі програмування Delphi 7.0. Для отримання зображення з відеодіагностичної апаратури використо-

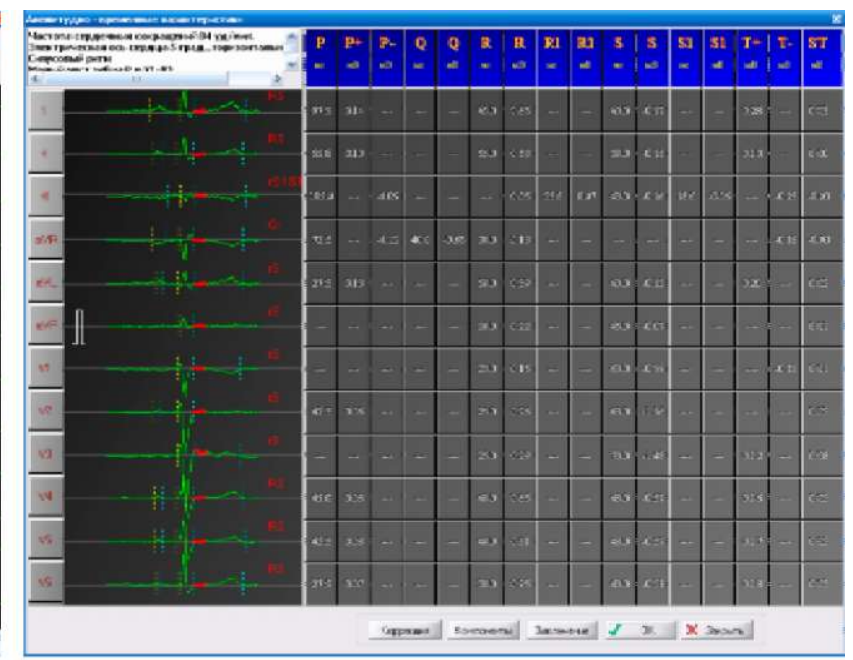

Puc. 3. Вікно програми "UNET" із цифровою інформацією щодо амплітудно-часових характеристик.

вуються компоненти 3 набору DSPack. Цей набір призначений для роботи з даними мультимедія і використовує технології MS Direct Show та Direct X.

Групи лікарів-інтернів (три в одному центрі) працюють почергово. Керівництво роботою здійснюють досвідчені викладачі кафедри поліклінічної справи та сімейної медицини й інших клінічних кафедр університету. Оперативне керівництво НПЦПМСД здійснює керівник, який підпорядковується і звітує про виконання навчально-практичної роботи студентами та інтернами проректору з лікувальної роботи. На базі НПЦПМСД є можливість засвоєння ряду практичних навичок, зокрема огляду хворих, ведення документації, роботи $з$ апаратурою, навичок в роботі із засобами віддаленого консультування.

За 2009-2011 p.p. в навчально-практичних центрах первинної медико-санітарної допомоги (табл. 1)

Таблиця 1. Показники діяльності в НПЦПМСД за 2009-2011рр.

\begin{tabular}{|c|c|c|c|c|c|c|c|c|}
\hline $\begin{array}{c}\text { Населений } \\
\text { пункт }\end{array}$ & $\begin{array}{c}\text { Прийнято } \\
\text { амбулаторних } \\
\text { хорих: (первин- } \\
\text { но/ повторно) }\end{array}$ & $\begin{array}{c}\text { Проліко- } \\
\text { вано } \\
\text { хорих на } \\
\text { дому }\end{array}$ & $\begin{array}{c}\text { Взято на } \\
\text { диспансе- } \\
\text { рний } \\
\text { облік }\end{array}$ & $\begin{array}{c}\text { Заповнено } \\
\text { амбула- } \\
\text { торних } \\
\text { карт }\end{array}$ & $\begin{array}{c}\text { Заповнено } \\
\text { статистич- } \\
\text { них } \\
\text { талонів }\end{array}$ & $\begin{array}{c}\text { Проведено } \\
\text { ін'єкцій/ } \\
\text { інфузій }\end{array}$ & $\begin{array}{c}\text { Прове- } \\
\text { дено } \\
\text { ЕКГ }\end{array}$ & $\begin{array}{c}\text { Пере- } \\
\text { в' язки }\end{array}$ \\
\hline Зарубинці & $355 / 358$ & 181 & 227 & 931 & 634 & $232 / 2$ & 185 & 33 \\
\hline Гнилиці & $267 / 726$ & 386 & 335 & 945 & 791 & $407 / 2$ & 175 & 117 \\
\hline Говилів & $442 / 401$ & 148 & 51 & 747 & 553 & $489 / 26$ & 369 & 126 \\
\hline Увисла & $189 / 124$ & 44 & 50 & 295 & 308 & $250 / 40$ & 115 & 37 \\
\hline Кокошинці & $39 / 50$ & 58 & 8 & 60 & 53 & 34 & 26 & 62 \\
\hline Всього & $1272 / 1689$ & 817 & 641 & 2978 & 2339 & $1412 / 70$ & 870 & 375 \\
\hline
\end{tabular}

було прийнято 2961 амбулаторних хворих: у с. Зарубинці - 723 хворих; с. Гнилиці - 993 хворих; с. Говилів - 843 хворих; с.Увисла - 313 хворих; с. Ко кошинці - 89 хворих.
За даний період проліковано на дому 817 пацієнтів, на диспансерний облік взято 641 жителя із вказаних сільських населених пунктів. Електрокардіографію проведено 870 пацієнтам, перев'язки зроблено 375 
хворим. Працівниками НПЦПМСД при цьому заповнено 2978 амбулаторних карт та 2339 статистичних талонів. До дільничного терапевта за вказані роки направлено 1157 пацієнтів.

Висновки. Покращення інформаційно-технічного забезпечення із впровадженням інформаційної системи на первинному рівні надання медичної допомоги дозволить вирішити такі задачі:

- оперативне отримання інформації для надання медичної допомоги;

- формування електронної картотеки пацієнтів;

- формування єдиного банку даних регіону;

- обмін інформацією з іншими лікувально-профілактичними закладами області через створення загальної інформаційної системи;

- консультування жителів провідними вузькими спеціалістами;

\section{Література}

1. Концепция информатизации здравоохранения в Украине / О. П. Минцер, Ю. В. Вороненю, Л. Ю. Бабинцева [и др.] // Медична інформатика та інженерія. - 2012. - ํ⒊ - С. 5-29.

2. Основи техніки передавання інформації: підручник /

Р. Н. Квєгний, М. М. Компанець, С. Г. Кривогубченко, А. Я. Кулик. - Вінниця : УНІВЕРСУМ-Вінниця, 2002. $198 \mathrm{c}$.

3. Кафедра Прикладных информационных технологий МФТИ Ийр ://^^^^йке.тір 1.ги/aii/

4. Концепция современного образования в области информационных технологий и опыт консолидации усилий по ее реализации / Ю. В. Гуляев, С. А. Никитов, В. Е. Анциперов, А. Г. Бабалян // Межотраслевая научно-практическая конференция "Кадровое обеспечение Федеральной целевой программы "Электронная Россия" : материалы конференции, М., 2002 г.

5. Методы разработки современных систем телемедици-
- формування єдиного банку даних регіону.

Показники лікувально-профілактичної роботи навчально-практичних центрів первинної медико -санітарної допомоги свідчать про ефективність інформатизації для покращення якості надання первинної медичної допомоги.

Впровадження інформаційних та телемедичних технологій дає можливість також підвищити ефективність підготовки висококваліфікованих спеціалістів для роботи у сільських населених пунктах.

Перспективи подальших досліджень. Подальші дослідження з удосконалення інформатизації роботи лікувально-діагностичних закладів на первинному рівні суттєво покращать підготовку лікарів на додипломному етапі та якість надання медичної допомоги жителям села.

ны. / Д. С. Никитов, 3. А. Сновида, В. Е. Анциперов [и др.] // Успехи современной радиоэлектроники. - 2004. - № 5-6. - С. 133-137.

6. Кобринский Б. А. От дистанционной диагностики к телемедицине: современные задачи / Б. А. Кобринский // Межд. симп. «Телемедицина 98» : тез. докл. - М., 1998. - С. 5-7. 7. Кобринский Б. А. Телемедицина в системе практического здравоохранения / Б. А. Кобринский // Приложение к журналу "Здравоохранение". - 2002. - № 2. - М., 2002. $175 \mathrm{c}$.

8. Ковальчук Л. Я. Результати реалізації новітніх методик навчального процесу в Тернопільському державному медичному університеті імені І. Я. Горбачевського та плани на майбутнє / Л. Я. Ковальчук // Медична освіта. - 2012. №2. - С. 11-17.

9. Клиническая телемедицина / А. И. Григорьев, О. И. Орлов, В. А. Логинов [и др.]. - М. : Фирма «Слово», 2001. - 144 с. 